\title{
WELCOME TO THE WORLD, TRILBY FREEDOM
}

\section{It's the age of enlightenment.}

\section{BY MARCELINA VIZCARRA}

$\mathrm{T}$ he whole cul-de-sac had been invited. Arabella lifted the visor to reveal her daughter's chubby face, fresh from her birth-year quarantine. "Her name's Trilby Libertas. It means Hat of Freedom," Arabella said. The other parents at Jared's table moaned in approval. It was a good coup in the clothing-name trend. You couldn't take two steps anymore without passing a Vesta or a Helmet, a Buckley or a Blazer. But a Trilby ranked up there with past icons like Snobia, Anavrin and Chyme for uber unique.

The party noise triggered the audio-contamination warning on Trilby's second womb. Arabella adjusted the baby's acoustic-foam headband. "Anything higher than 85 decibels can damage hearing," she announced. The parents murmured in agreement.

The kids at the indoor park lolled inside their transparent filter-suits like unhardened vegetables. When Jared was a child, the dome's climbing walls and tunnels were attempted with bare hands, the bacteria-andsugar mucilage an inevitable, occasionally welcome, form of traction. Hed used the gunk once to grease Arabella's ponytails. The next day at school, shed appeared with a fresh pixie cut and a zero-tolerance policy in her hand.

"Swimming lessons!" Merit's voice flared with mock-indignation. "Right! One lifeguard per ten kids."

Enlightened parenting. Jared's leastfavourite default conversation. Better to pitch in, though, than to allow his silence to be mistranslated throughout cyberspace as aloofness again. And end up on the apathypolice's radar. Talk about creepy fora. "We can't blame our folks," Jared said. "They didn't know any better."

"Society wasn't ready."

"Exactly. My mother was ridiculed for putting me on a leash."

"Speaking of inhibitors, what about those car seats!" Seattle said. "Remember those? Like our backs were somehow more important than our organs."

"Those harnesses caused my lactose intolerance."

A chorus of beeps alerted the parents to the passage of time, and they turned in unison to monitor their children. At least, here, with the kids safely herded, they didn't

have to suffer the child-hostile public spaces, the nanny drones following them through supermarkets and shopping centres.

"My gripe: the backyard playsets," Arabella said. "My mom used to send me outside by myself every afternoon."

"Me too," Seattle said. "Once, I played with cat faeces for an hour before she came outside and told me what it was. Toxoplasmosis, anyone?"

Bangle rolled over for a portion of glutenfree, nonallergenic, free-radical-blasting vitamin pulp. Jared leaned as he shifted in his chair, setting off the girl's proximity alarm.

"Christ, I had no idea I was that close." He apologized profusely to Bangle's mother who, being gracious, recoded the alarm.

"Don't worry. I know you're not a perv." She laughed. She'd checked him against the registry two weeks earlier when he complimented Bangle's dress. "Meet Trilby, Bangle. Not so close, honey. Stay behind the sensor."

Too late. The womb pulsers discharged, delivering a preliminary, non-lethal shock.

"I got bit once from my great-grandson's carrier," an old man said. One of the relics from the cul-de-sac. "Remember when you'd shock your fingers against the doorknob after walking across the carpet? It's about like that." He made a buzzer sound and poked Jared in the shoulder.

The others regarded the man with pity. $\mathrm{He}$ coughed into his fist. On cue, they pulled out their pocket sanitizers and masked themselves, effectively ending the chat.

Arabella narrated into her diary for the benefit of her 8,000 followers. "Having a blast. Trilby's met everyone except Panto." She raised her eyebrows at Jared. He shuffled through the apps on his diary to summon his son from the pretzel slides. The action posted online, where half a dozen people including

$\rightarrow$ NATURE.COM

Follow Futures: y @NatureFutures

f go.nature.com/mtoodm a retired couple in Montana and Jared's mother in Florida reposted the event.

Panto wheeled over.
Jared had chosen the name in panic after his rival neighbours announced their twins, Sari and Knickerbocker. At least he'd never force his son into friendships with the snobby twins. Gone were the days of the shoving, pinching, sticky touch of childhood, the adhesion of germs and bad decisions and parental disinterest that used to form bonds between kids. Perhaps the parenting enlightenment had accomplished something after all, Jared thought.

"A toast," the elderly man said, lofting a tumbler of carbon- and politic-neutral banana splash, "to the little lady on her first birthday. Welcome to the world, Trilby Freedom." Arabella winced.

"Hear, hear." They quaffed their juice while Trilby chewed on her crib mentor, a plush kangaroo translating their every word into Mandarin and Japanese.

"And," Jared said, rising to his feet in a rare fit of self-promotion, "to the sacrifices we've made for our children. Thanks to modern understanding, they can pursue real friendships, based on respect instead of proximity."

His neighbours blinked and paused, then, pleased with Jared's epiphany, self-attributed it in their diaries. Panto hugged himself, signalling Bangle to hug herself in response. They finished with an air high-five, delivered, by the push of a button, with a cymbal clash.

On cue, the sandwiches arrived in their own dome. The server detailed the chicken salad's previous incarnation as animal and vegetable and offered to list toxin exposure for each ingredient. Arabella waved away the server. "We're not fascists here. I mean, we survived our parents' menu."

"Back in the day, before free-range food."

"'Honey, your dinner was clinically depressed. Enjoy!”

Jared relaxed. Free-range food, air and sunshine. At last, something everyone could agree upon. -

Marcelina Vizcarra lives in the Midwest with her family. 